\title{
NMR イメージング法の固体材料への応用
}

\section{齋 藤 公 児*}

\section{Application of NMR Imaging to Solid State Materials}

Koji SAITO (Nippon Steel Corporation Advanced Technology Research Labo. 20-1 Shintomi Futtsu City, Chiba, 2938511, JAPAN )

NMR imaging is most widely known, where the method has become an invaluable tool complementing X-ray tomography. But in the first reports of NMR imaging, both medical and materials applications were considered. Though the achievable spatial resolution is limited practically in fluids and soft solids, it was known already that NMR provides image contrast is fundamentally different from that of other methods. The contrast is determined not only by the density of observed nuclear, but also by the numerous other parameters, which are measured in NMR spectroscopy to investigate the molecular characteristics of condensed matter. These parameters include relaxation parameters which depend on the physical properties of the sample. In solids, also the size and orientation dependence of different spin interactions can be analyzed for contrast parameters. In this report, a basic principle of NMR imaging and a industrial application of NMR imaging (solvents ingress to rubber ) are shown. And also, NMR-MOUSE, which is typical simple technique, has many applications in order to clarify properties at outisde. By mapping suitable NMR parameters over the sample volume, structures invisible to other methods may be determined. Within the limits imposed by the probe and magnet dimensions the method is nondestructive to the sample.

Key Words : NMR, NMR imaging, contrast parameters, solid state materials, NMR-MOUSE(outside NMR)

\section{1.は じめ に}

NMR(Nuclear Magnetic Resonance：核磁気共鳴)法は その名の通り, N (Nuclear 核)， M (Magnetic 磁気/磁 場) R (Resonance 共鳴)で説明できる.ほとんどの元素 には核スピンが存在し，それらは幸運なことにほとんどが NMR 測定の対象 (感度の善し悪しはあるが)となるＮMR 法は簡単には, $\mathrm{N}$ (核)を $\mathrm{M}$ (磁場) 中に置くと, エネルギー 分裂が生じ，その分裂の大きさに合わせて, $\mathrm{R}$ (共鳴：そ のエネルギーに合わせてラジオ波で共鳴)を起こさせる方 法である. 得られる情報は, 化学シフトと呼ばれる化学構 造情報に敏感な数值で, 隣にどのような元素があるかに強 く依存して, その共鳴位置が異なる、X線と比較すると, 化学構造の短距離情報に敏感であることから, ゴム産業や 高分子化学や有機材料科学の分野で広く利用されている. 日本にNMR 実験の装置は非常に多く導入されており，製 造業に携わる企業では, 各社 1 台程度は保有している場合 が多い. しかし 10 年くらい前までは, 高分子以外の分野 に関する実用固体材料解析にNMRが非常に有効であった
という報告例はあまり多くなく，固化する前の塗料の化学 構造解析等が主であった ${ }^{1)}$ 。これは，この手法が高分子以 外の産業に関わる実用固体材料に対してあまり有効な情報 を与えない，あるいは与えることができないと考えられて いた結果と思われる. その原因は化学シフトのみが固体 NMRの重要な情報と考えられていたためであろう．しか し先に説明した化学シフト以外に, NMR法から得られる 特筆すべき情報には，核磁気緩和 (relaxation) 時間がある. 緩和現象は他の分光法 (IR ラマン)でも観測されるが, 核磁気緩和の特徵は「その時間(緩和時間)が簡単に測定で きるくらいに十分遅い」ことが特徴である ${ }^{2)}$ 。つまり，こ

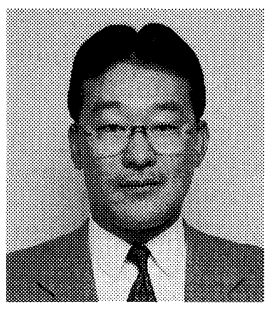

*新日本製鐵(株)先端技術研究所 ( ₹ 293-8511 富津市新富 20-1) 主幹研究員. 理博. 昭和 59 年, 名古屋工業大学大学院化学系修士課程修 了。同年，新日本製鐵(侏)入社，現在に至る。 専門は, 物理化学, 核磁気共鳴 (固体NMR及 びNMRイメージング) とその実用材料への応 用. (社)高分子学会 NMR 研究会運営委員長. (社)日本分析化学会理事.日本核磁気共鳴学会理 事. 他 
の緩和時間は $\mu \mathrm{s}$ 程度以上に遅く且つ化学構造やその存在 状態に敏感で, 様々な物質や材料の特性と良く相関してい る場合が多い，例えば高分子での架橋密度や劣化状態等は その緩和時間に顕著な差を与える場合が多い。その緩和時 間をコントラストのベースに利用したNMRイメージング 法3) は, 今や脳ドック, 血流計測を含めて医療での臨床分 野では欠かすことの出来ない非破壊検査法となっている. 最近になって, 高い磁場勾配の実現等のハード面の進歩に よって, NMRイメージング法は実用材料への応用が広が って来ている ${ }^{4)}$. 本手法は, 緩和時間が劣化等の材料内部 構造の情報を反映したり, 加熱等による経時的な変化と敏 感に関係していることから，それらをコントラストとして 非破壊で観測できるため, 今後の発展が強く期待されてい る.特に鉄鋼プロセスや周辺材料系は不均一な材料が多く, 分布や化学変化等の情報が必要な場合も多い，筆者らは 様々な鉄鋼プロセス及びその周辺材料に関して, NMRで の化学シフトとは別の特徴である緩和時間を基本原理とし て利用されているNMRイメージング法の応用を実施して いる. 本稿はゴムに近い材料を意識し, それら関する応用 例を中心に解説する.

\section{NMRイメージング法の概要}

NMRイメージングの原理を図 1 に示す。基本的に NMRで使用される静磁場中に試料を置いた場合, 試料が 感じる磁場強度は同じであるため, 図 1 中でのロと○の区 別はできない. しかし，外部から傾斜磁場が与えられた場 合，口と○の感じる磁場強度がわずかに異なるため, その 違いを位置情報に転換することで，画像化が可能となる． 画像化には，信号強度以外にも NMRの持つ緩和時間をコ ントラストパラメータとして利用し，濃淡をつけることが できる. 本手法の特徴は, (1)非破壊 3 次元内部計測手法で あること，(2)様々なコントラストが利用できること，(3)変 化や流れの測定ができることにある．基本となる磁石や分 光計という通常の NMRに必須な装置以外には, 図 2 に示 したように磁場勾配を発生する電源と磁場勾配コイル，お よび検出するためのプローブである．特にプローブは対象

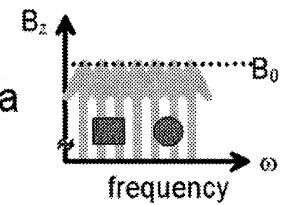

b
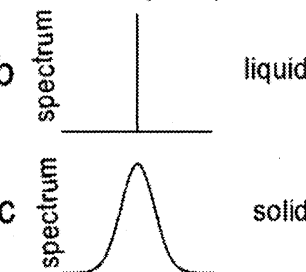

図 1 NMRイメージング法の原理
材料に応じて，様々な形態が存在している，測定後はフー リエ変換等により，画像を構築する，基本的にNMRの原 理から，検出感度は高いとは言えない。また検出核は ${ }^{1} \mathrm{H}$ で，空間分解能も $1 \mu \mathrm{m}$ 以下にならない. しかしながら， コントラストパラメータが多様であり, 条件の最適化がで きれば，非破壊性を活かした応用が可能である。実用材料 への応用は歴史もせいぜい 10 年程度であるが，ゴムや柔 らかい高分子材料の非破壊内部解析への試みは，線幅が狭 く技術的にも比較的容易なため多くの実施例がある.また 最近は新たな装置開発や手法開発が進み，固い材料への応 用や材料中の流体流れ解析等, 様々な分野への適用が拡大 している．特に実用材料には，不均一材料が多く存在し， その非破壊計測法を利用した解析の果たす役割は大きい。 具体的な例として図 3 に，オイルガスケットへのオイルの 膨潤による変化の場合を示す ${ }^{4)}$ 。このような技術を利用し て、破壊前の内部情報を検出することができる．本手法を 利用して様々な変化過程の解析や連続定点観測・解析等 で，実用材料の新しい知見を得ることができる.

$$
\text { 3. コントラストパラメータ5) }
$$

NMRイメージングには緩和時間がコントラストパラメー

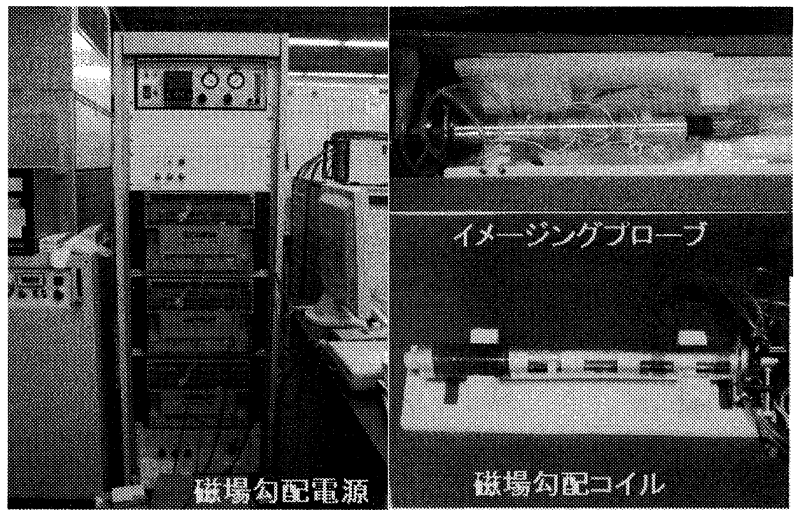

図 2 NMRイメージング法に必須となる磁場勾配電源及び磁場勾配 コイルと検出プローブ

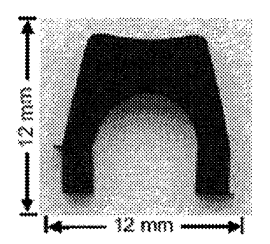

\section{Soft Matter Contrast}

oil gasket after thermal load

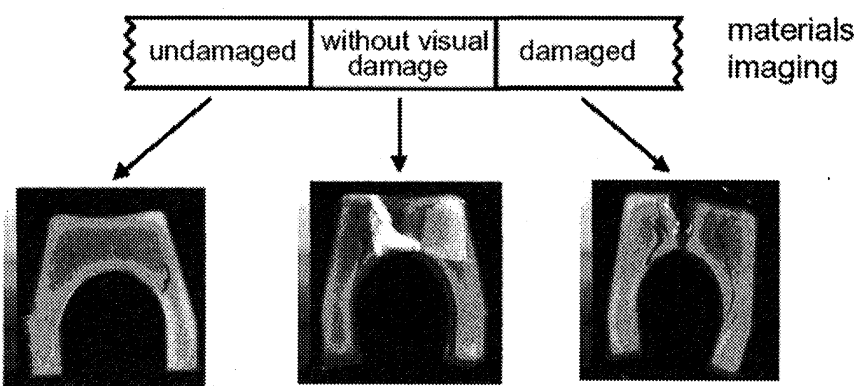

図 3 オイルガスケットでのNMRイメージング結果 


\section{Interface in Unfilled NR/SBR Co-Vulcanizate}

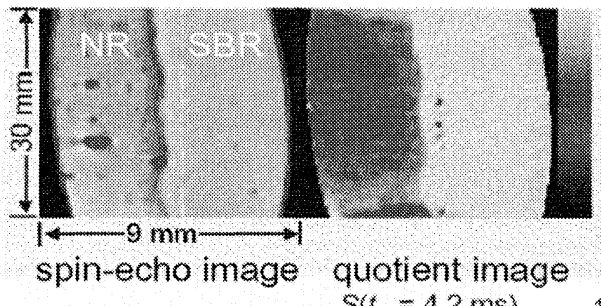

$$
s\left(t_{E}=3.3 \mathrm{~ms}\right) \quad \frac{s\left(t_{E}=4.2 \mathrm{~ms}\right)}{s\left(t_{E}=3.4 \mathrm{~ms}\right)}
$$

spin-echo imaging

$$
M_{z}\left(t_{2}, t_{0}\right)=M_{0}\left(1-\exp \left(-t_{2}\left(T_{1}\right)\right)\right.
$$

single-point imaging

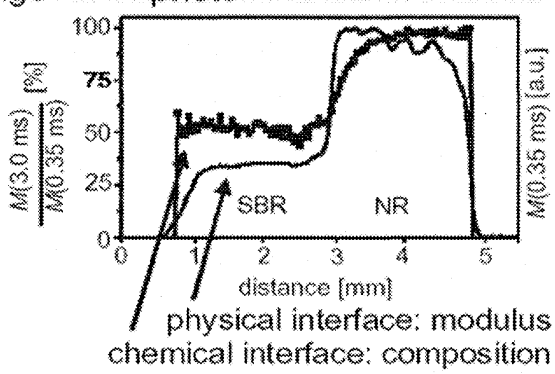

図 4 ゴムに扔けるコントラストパラメータの寄与

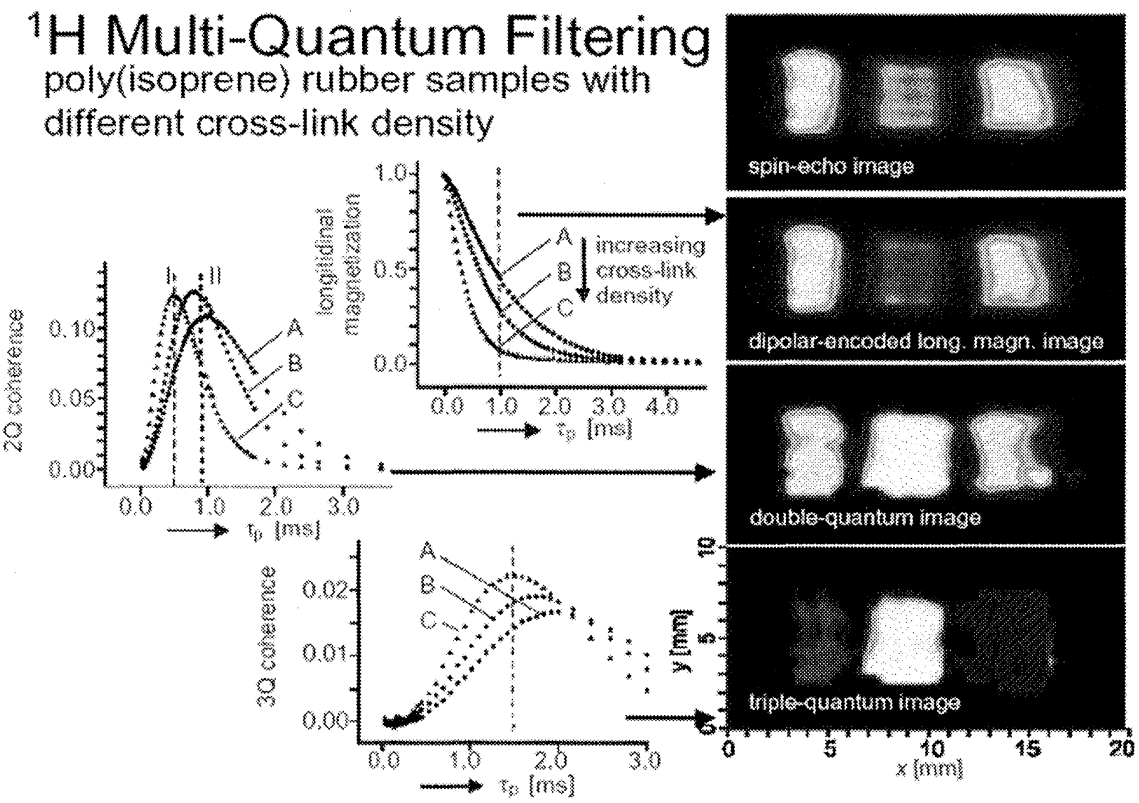

罒 5 架橋度の異なるゴム材料での測定法と得られるコントラストの差違

タとして重要な役割を果たしていることを先に説明した。 ここではゴム系の材料で，具体的に解説する。図 4 に，典 型的な天然ゴムと合成のスチレンブタジエンゴム（以下 NR，SBR と呼ぶ）を貼り合わせた試料のNMRイメージン グの結果を示した。NMRイメージングでの標準的な手法 であるスピンエコー法では，両者の界面部分が非常に差違 が明確である。一方 NRと SBRの差違は明確ではない．ス ピンエコーでのコントラストパラメータであるエコー時間 の比をとると明確になるが，逆に界面部分はあまり明確で はなくなる．このようにコントラストパラメータの選択が 非常に重要で，緩和時間 $T_{1}$ と $T_{2}$ に低存していることが図 4 を見ると一目瞭然である.

コントラストパラメータは緩和時間だけでなく，他にも 色々とある．図 5 にポリイソプレン製で 3 種類の架橋密度
の異なるゴムのNMRイメージングの結果を示した。普通 のスピンエコー法，双極子相互作用を強調した dipolar-filter 法，更に 2 量子， 3 量子を利用した各qunatum-filter 法の 4 種類の測定結果は 3 種類の架橋度の異なる試料によ って，そのコントラストが変化することがご理解いただけ ると思う。このようにコントラストが異なる原因は，利用 している測定法がどのコントラストパラメータに強く依存 しているかである.眓 5 の左側に示したグラフがその挙動 をよく説明している。その他ゴムに外部から压力を掛けた ときの内部の状況変化や加熱したときの挙動等，様々な状 況でもコントラストパラメータを選ぶことで，多くの情報 を得ることができるため，ゴム系材料へのNMRイメージ ング法の応用例は非常に多い4). 


\section{4. ゴムベルト材料への溶液の浸透過程解析 ${ }^{6)}$}

製鉄所では原燃料の搬送に多くのゴムベルトが利用され ている.実際には図 6 に示したようにゴムベルトが膨潤し， 搬送不能に陥るトラブルが多々あった.その主原因は, ゴム ベルトへのタールの浸透と考えられるが，そのメカニズム は不明な点が多かった．そこでゴムベルトにタールがどの ように浸透し且つそのメカニズムを検討するために，ター ルのモデルとして，ピリジンとアセトンを用いた。このモ デルと実際のタールを使用して浸透過程をイメージング法 で非破壊追跡した。

ゴム搬送ベルトはポリブタジエン系で張力強化の意味 で，ナイロン纎維での強化が施されている．測定は $9.4 \mathrm{~T}$ の WB-SCM で58T/m の磁場勾配下で, Chemagnetics (VARIAN)CMX-400 Infinity 及び自製のプローブで行っ た. 1 次元のイメージング測定を共鳴周波数は 236.82 $\mathrm{MHz}$ ，パルスシーケンスはquadrature echo sequenceを 使用し， $\tau$ 時間は $60 \mu \mathrm{s}$ で実施した。代表的な積算回数は

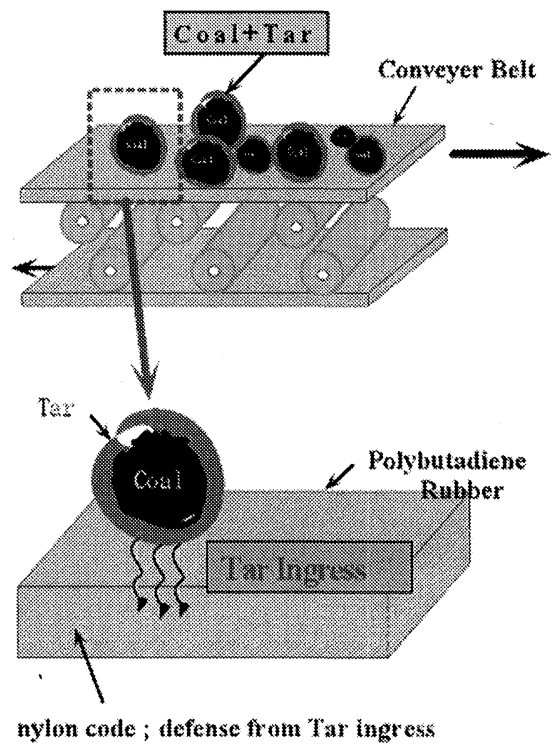

図 6 ベルトへのタール浸透の概念図

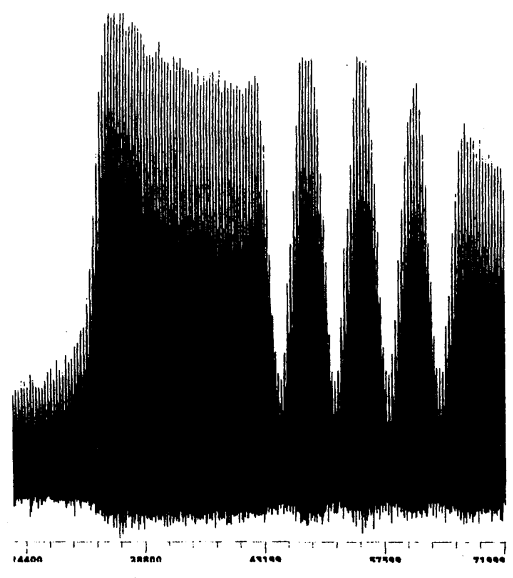

図 7 NMR一次元イメージングの測定結果
32 回程度で, 約 0.5 時間毎に測定を実施し，in-situで浸透 過程を追跡した，磁場勾配量が一定であるため，試料を機 械的に動かす事で位置情報を得た。図 7 に典型的な NMR イメージングの一次元の測定結果を示した．ひと固まりの 測定結果の中はFID 信号の集団であることが容易にわか り，それぞれが測定に際して試料位置を動かした結果に対 応している。つまり横軸は位置情報を反映している。この 各FID 信号に，例えばdouble-exponential 曲線を fitさせ， $T_{2}$ の long 成分と short成分を得て，各位置における $T_{2}$ 值や 成分比をつなぎあわせる事でイメージング profileを作り 出すことができる．アセトンとピリジン溶媒の浸透現象追 跡をイメージング法で追跡した結果を図 8 に示した。時間 経過につれて，溶媒がゴムベルト中に浸透し，徐々に信号 が増加していることが明らかにわかる．また興味深いこと に，ナイロンコード以降への溶媒の浸透は観測されず，張 力強化のためのナイロンコードが溶媒による膨潤も防いで いたことがわかった。この結果を利用して $\mathrm{Y}=\mathrm{AX} \mathrm{X}^{\mathrm{B}}(\mathrm{Lev}$ enburg-Marquardt)の回帰でフィッティングした場合5), A，Bが浸透過程の性質を表すパラメータとなる。一般に Bの值が 0.5 程度で Fickian 型拡散, 1.0 程度でCase II 型拡 散と考えられる ${ }^{6)}$. 解析の結果，ピリジンはCase II 型拡 散，アセトンはFickian型拡散と帰属された。上式を解く とアセトンでは $\left(\mathrm{A}=0.39, \mathrm{~B}=0.42, \mathrm{D}=2.11 \times 10^{-11} \mathrm{~m}^{2} / \mathrm{sec}\right)$, ピリジンでは $\left(\mathrm{A}=0.48, \mathrm{~B}=0.93, \mathrm{D}=2.54 \times 10^{-11} \mathrm{~m}^{2} / \mathrm{sec}\right)$ と 拡散係数を得ることでき，コンベアベルトの膨潤のメカニ

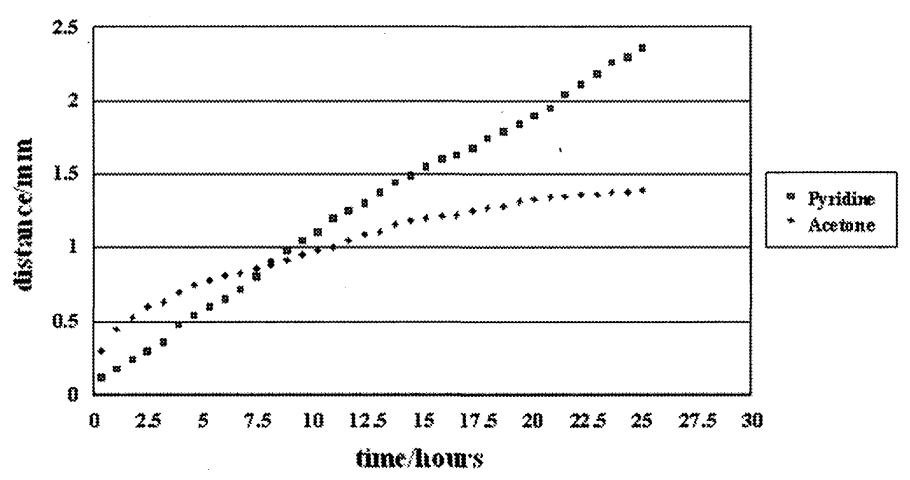

図 8 ベルトへのアセトンとピリジンの浸透過程の差異

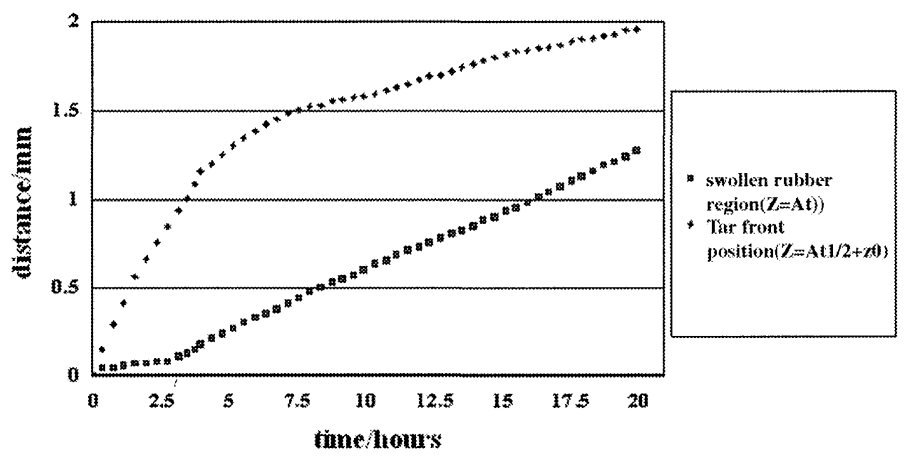

図 9 ベルトへのタールの浸透過程のベルト自身の膨潤の変化挙動 
ズム等を検討する上で貴重な情報を得た，実際の現場で上 記の知見を利用して,タールでの浸透過程実験を実施した。 タールはピリジンやアセトン以外に様々な溶媒が混在して おり，その浸透過程のメカニズムは非常に複雑で，図 9 に 示すようにタールの浸透パターンとゴムの膨潤パターンが 異なることがわかった．観測は先に説明したように，ター ルにコントラストを合わせる実験とゴムにコントラストを 合わせる実験を併用することで，両者の挙動を知ることが できた。 その結果, タール揮発成分の挙動が表面側で flux が強く作用しているためと考えられる．また他の溶媒成分 がFickian 型拡散と Case II 型拡散でベルトに浸透していく 現象が混ざり合った挙動となっていると考えられる，2つ の混合溶媒の系で同様の実験を繰り返すと, 表面での flux が減少するにつれて Fickianから Case II に移行することが わかっている ${ }^{5)}$ 。この場合も同様の解釈となると考えてい る. 実際の現場のようにタール中の揮発成分が多く存在し ている場合には，まずタール中のアセトン等の成分が Fickian型拡散で浸透し，その後揮発成分が表面近傍でな くなるにつれて，ピリジン成分等によるCase II 型拡散に 変わっていくと推定できる．またその結果，膨潤挙動は時 間遅れが生じてゆっくりと起こっている。このように， NMRイメージング法は材料に液体等が浸透する過程を非 破壊で解析し有効な知見を与える方法であることがわか る. 液体の浸透を観察できることは, 逆に液体の乾燥を見 ることも可能であり, 我々は本手法を利用して材料の乾燥 過程の解析も行っている7).

\section{5. 屋外でのNMRイメージングの概念を利用する例 ${ }^{8-9)}$}

最近実際に現場で使用されている材料をその場で診断し たいというニーズが出てきている，つまり，従来実験室を 中心とした分析研究者もフィールドワークをする必要があ り，屋外で活用できる分析・診断法の確立が急務となりつ つある．従来 NMR 法は実験室レベルでは高分子皮膜の劣 化解析に有効であったが, 屋外での使用は不可能であった. 最近Bluemich らによってNMR-MOUSE (MO bile Universal S urface Explorer) 法 ${ }^{10)}$ が開発され，屋外での ゴムタイヤ等の実材料の測定・解析が可能であることがわ かってきた，その概要図を図10に示した．従来の超電導 磁石の代わりに天然磁石を組合わせて, NMRイメージン グで説明した磁場勾配機能を磁石自体に付与しており, 全 体のシステム構成も非常にコンパクトになっている. 100 $\mathrm{V}$ の電源さえあれば, 屋外でもイメージングの測定が可能 となる.屋外での自動車用タイヤの劣化挙動等への応用を, 今回筆者らは鉄板上にコートされた高分子皮膜の劣化解析 にNMR-MOUSE法を適用してみた。

鉄板上 (1.5 mm 厚)に $500 \mu \mathrm{m}$ 厚の polyvinylchloride (PVC)がコートされているものを試料とし，それらを $\mathrm{S}$

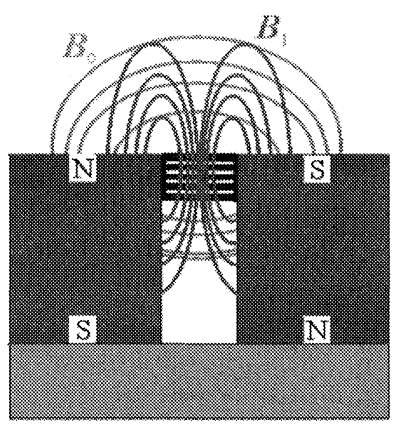

\section{Schematic drawing of the NMR- MOUSE}

図10 NMR-MOUSEでの磁石構造

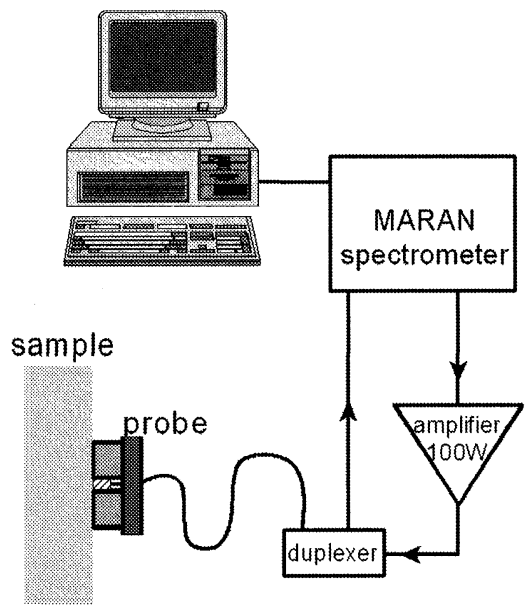

図 11 NMR-MOUSEの装置概要

WOM(S unshine Weather $\underline{\text { Of }} \underline{\text { Meter}})$ 装置にて, 紫外線 照射 (280 450nm, $370 \mathrm{~W} / \mathrm{m}^{2}$, 約 2 時間) と水滴噴霧 (約 20 分)を 1 サイクルとする劣化処理をそれぞれ 0,100 , 300，500，1000，2000，3000時間行った。

測定は自作の NMR-MOUSE装置 ${ }^{2)}$ で行い， $T_{2}$ の測定 は改良型 steady-state C PMG シーケンスで行った．共鳴 周波数は，約 $21.4 \mathrm{MHz}$ であった，基本となる装置構成を 図 11 に示した．鉄板の有無による影響の比較のために行 った $T_{2}$ 測定は，上記試料を鉄板から引き剥がした後， NMR-MOUSEで行い, 同時にChemagnetic 社のCMX300 でも行った. NMR-MOUSEでの測定時間は, 約 15 分 であった.

測定結果は緩和時間が 2 種類存在するので, doubleexponential で緩和時間を算出すべきであるが，鉄板が存 在する場合, slow成分の磁化の減衰状況がノイズが高い ために明確ではないことから, mono-exponential関数で の処理を行った．図 12 に鉄板上の皮膜の測定の様子と劣 化処理 0 時間 (未処理) と 3000 時間の試料の NMRMOUSE 法で測定した結果を示した。明らかにNMRMOUSE 法で，鉄板上の P V Cの $T_{2}$ を測定できていること がわかる．また 3000 時間の劣化処理試料の $T_{2}$ が，未処理 


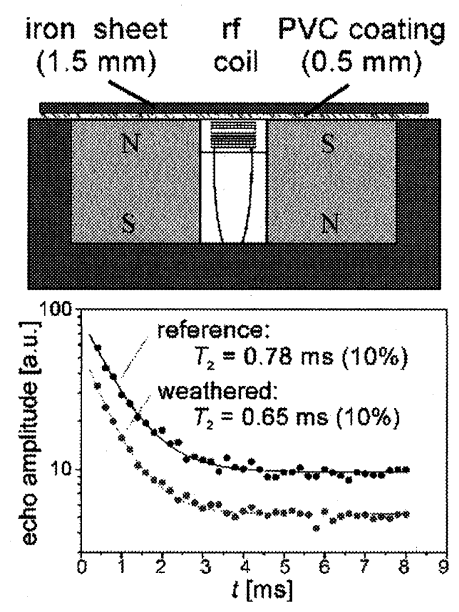

図12 NMR-MOUSEでの測定結果

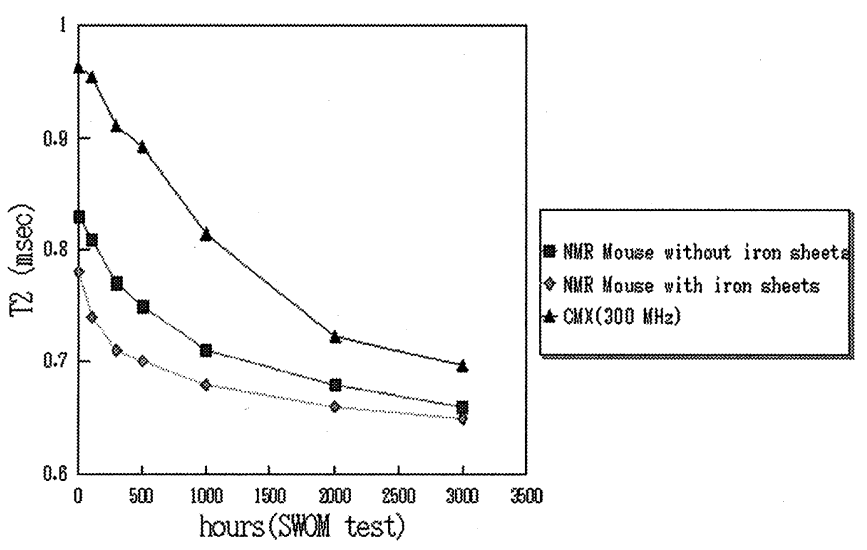

図13 NMR-MOUSEでの測定結果

の試料のそれと比較して短くなったことがわかった. 図 13 に各劣化処理をした試料について，NMR-MOUSE 法 で鉄板有りと無しの場合, 及び鉄板から剥がし通常の固体 NMRで測定結果を併せて示した。 $T_{2}$ の絶対值は異なるが, 様々な高分子の劣化について既に報告されているように, $T_{2}$ が減少する傾向は一致している．また，劣化処理が初期 の頃に対しても，非常に鋭敏に $T_{2}$ が変化していることが わかり，本法はPVCの初期劣化に対する感度が高いと考 えられる.このPVCの $T_{2}$ の減少の理由として, 紫外線照 射に伴うラジカル濃度の向上, それに伴う化学結合の切断, 紫外線照射に伴う試料温度の上昇による揮発分の減少等が 考えられ, 結果としてPVCの mobilityが失われ, dipolarcoupling 強調されたためと推定される.

以上のようにNMR-MOUSE 法で，鉄板上にコートさ れたPVC皮膜の劣化程度を簡易的に判定できることがわ かった. SWOMでの劣化処理は，自然の天候をモデルに 作られており, 鉄板上の高分子皮膜の劣化試験として広く 使用されている．我々はポリエステル系の高分子皮膜でも 同様の結果を得ており，今後本手法が屋外での鉄板上の高 分子皮膜の劣化判定に活用できると考えられている．また
最近問題となっている屋外でのコンクリート内部劣化診断 にも応用可能と言えよう。また, 原理がNMRイメージン グであるので, 先述したような溶媒の浸透過程の解析も可 能である.
6. ま
と
め

最近のNMRイメージング手法に関して，ゴム材料や鉄 鋼関係周辺材料への応用例や屋外利用への展開を中心に解 説した。臨床分野では汎用であるNMRイメージング法も, その材料への応用はまだ始まったばかりと言っても過言で ない. しかしNMRイメージング法は, 従来の他の手法に ない, 化学構造やその状態に敏感であり, 様々な物質や材 料の特性と良く相関している緩和時間をコントラストのベ ースに利用している．同時に非破壊で材料内部構造の情報 が得られ且つ経時的な変化を観測できるため，今後の材料 への応用発展が強く期待される. 本総説では割愛したが, 筆者らは $600{ }^{\circ} \mathrm{C}$ まで加熱しながら材料内部を観測できる装 置を開発して, 石炭の軟化溶融過程の観測に成功してい る $^{11-13)}$ 。材料の開発には，必ずそれを観測・解析する手 法が必須であり, NMRイメージング法の特徽を活かした 応用が益々進み, 新たなプロセス・材料創出へと繋がるこ とを期待する。

\section{References}

1 ) Mamezuka, H. : Tetsu-to-Hagane, 77, 2179 (1991)

2) Saito, K. : Feramu, 8, 43 (2003)

3 ) Lauterbur, P.C. : Nature, 242, 190 (1973)

4 ) Bluemich, B., Bluemler, P., Saito, K. : Ando, I. , Asakura, T. Ed 'Solid State NMR of Polymers', Elseiver, 123 (1998)

5 ) Bluemich, B. : "NMR imagig of materials", Clarrendon Press, Oxford, 2000

6) Saito, K. : Bouseikanri, 48, 1 (2003)

7 ) Saito, K., Kanehashi, K., Saito, Y. , Godward, J. : App. Magn. Reson., 22, 257 (2002)

8 ) Saito, K., Zimmer, G., Bluemler, P., Bluemich, B. : Adv. Mater. 9, 987 (1997)

9 ) Bluemich, B., Bluemler, P., Eidmann, G., Guthausen, A., Saito, K., Zimmer, G. : Magn. Reson. Imaging, 16, 479 (1998)

10) Eidmann, G., Bluemler, P., Bluemich, B. : J. Magn. Reson., 16, 479 (1996)

11) Saito, K., Kanehashi, K., Komaki, I. : Annu. Report. on NMR Spectroscopy, 44, 23 (2001)

12) Saito, K. : Materia, 41, 878 (2002)

13) Saito, K., Hatakeyama, M., Komaki, I., Katoh, K. : J. Mol. Struct., 602, 89 (2002)

\section{日本語表記参考文献}

1 ）豆塚廣章：鉄と鋼，77，2179 (1991)

2）齋藤公児：ふえらむ，8，43(2003)

6 ）齋藤公児：防錆管理，48，1 (2003)

12）齋藤公児：まてりあ，41，878 (2002) 